\title{
A Personal Narrative
}

SALLY ALONZO BELL, PHD, LCSW

PROFESSOR EMERITUS, DEPARTMENT OF SOCIAL WORK AZUSA PACIFIC UNIVERSITY, AZUSA, CALIFORNIA

"Born and raised in East Los Angeles, fourth in a family of nine." This statement can be so misleading-hidden behind it are the struggle, anguish, pain, and often disappointment that are shared by Mexican American people in this society.

Both my parents were orphaned very young. My father was born in Michoacán, Mexico, and raised by an older sister in a very poor "rancho" that did not have running water, indoor plumbing, or electricity until the early 1960s. His poverty and rural existence denied him the opportunity of any formal education. Consequently, he taught himself to read and write in Spanish as a young adult. My father came to the United States at the age of fourteen, both to help send money to support his elder sister and three brothers and to fulfill his adolescent need for danger and excitement. He found life in the United States hard and unforgiving as an adult. He became an alcoholic, married young, and was widowed at thirty-five with three young boys. He married my mother, who was eighteen.

My mother was born in Mesa, Arizona, in the United States. She was orphaned by her mother at the age of six months, and orphaned by her father when she was six years old. Her old, rheumatoid, and arthritic paternal grandmother became her guardian. But, in all actuality, this tiny sixyear-old became the caretaker and breadwinner. My mother and grandmother lived most of their lives in Mexico, suffering famine, drought, political unrest, and hunger. Since survival occupied all of my mother's energy, there was no time for a formal education, but somehow through desire and native intelligence, she taught herself to read and write in Spanish. At age eighteen she married my father, with hopes of finding a beginning, a new life, and most of all, being loved and cared for.

Family life became more and more difficult with the birth of each child. 
My father continued to have longer and more frequent alcoholic binges, and consequently was less able to keep his various construction jobs as a bricklayer. All the while my mother was determined to keep her marriage and family intact. By 1948, my father's health, due to alcoholism, had deteriorated to the point that doctors warned him that he could die. He was frightened into sobriety for the rest of his life.

My father was convinced that his fate, as well as that of all Mexicans in America, was to be poor, landless, and subservient. Thus, he accepted his lot. My mother, on the other hand, had cloistered hopes and dreams that she began to project onto her children. For her generation and class, the optimum dream was a high school education. Every night she sat with each of us guiding us through our homework despite the fact that she did not know English and had little notion of what it was that we were doing. Two miracles began to emerge: the realization of the value of an education and my mother teaching herself to read, write in, and speak English. However, the abyss between the American culture and the Mexican culture proved too great.

Poverty, social class, and the lack of opportunity forced my mother to look to migrant work as a way to keep the family together and dare to dream of making enough money that eventually we could make a down payment on a house. My father left us in San Martin, California, choosing to live in a converted chicken coop (the "conversion" involved nothing more than throwing out the chickens), with no indoor plumbing, a woodburning stove, and an icebox. He joined us three weeks later after realizing that we actually had made some money.

We did migrant work from 1950 to 1959, my siblings and I leaving school in May and returning in late October. Thus, school became a hardship; we were always behind, academically and socially. This took its toll. While we all did finish high school, I was the only one to go on.

My road to academia was not an easy one. While my mother valued school, she and my father perceived it as a luxury. And, as a luxury, it therefore was not work, so we were always expected to carry on our traditional roles and fulfill cultural expectations. What this meant for me was that I had to work in the home as well as outside the home in order to contribute to the well-being of the family. My parents were also suspicious of school and concerned that we would learn the loose ways of "Anglos," so I had to "sneak" literature that was not in the form of a textbook. My parents were also concerned that too much reading would hurt my brain and damage my eyes, so they would turn off the electricity at the fuse box at 11:00 p.m. Of course, you have to realize that because of 
house chores, part-time employment, and classes, 11:00 p.m. was when I often got around to studying. But necessity is the mother of invention; I learned to read under the covers with a flashlight, as they would check for light filtering from under the door.

School also posed its own obstacles. When I entered kindergarten, I spoke only Spanish, but the school went ahead and administered an IQ test, and a borderline mentally retarded label was promptly affixed. This hounded me until junior high school, when it occurred to someone that I was receiving excellent grades.

Junior high (Belvedere Junior High in East Los Angeles) was no fertile ground either; I had to fight tooth and nail to be allowed into the college track. Throughout this time no one, especially school counselors, spoke to me about college, but it was a notion that somehow floated in my head, placed there by these "bad Anglo" novels I had read.

Roosevelt High School in East Los Angeles was likewise no fountain of inspiration for Chicanos. There, my counselors, through their benevolence, advised me to take a vocational course-cosmetology. They felt that I would at least have a trade that I could support myself with, since my inability to finish high school and equal potential for an early pregnancy seemed clear. Fortunately, I did not take their advice. I took a college prep track, became a school council leader, joined the honor society, and earned many athletic awards (but no letter sweater, as we could not afford it).

I entered East Los Angeles Junior College in 1962 with a Roosevelt Alumni Scholarship, and then Helen Miller Bailey, $\mathrm{PhD}$, "happened to me." She encouraged, cajoled, and inspired me and the few other Chicanos on campus. She helped me realize that my dream of a baccalaureate was more than a remote wish. During this time I received three honors, full scholarships to study a summer each in New York; Maryland/Washington, DC; and Puerto Rico. I received the Associate of Arts Degree in 1966 and received a Happy Latins Businessmen's Award. I transferred to California State University, Los Angeles (CSULA).

I attended CSULA from 1966 to 1967 and dropped out when I married. My family would not accept my marriage without my working full-time for at least one year and contributing financially to the household: "All this time in college and you go off and get married without our benefiting?" Under all this stress, my grades plummeted and I was forced to leave. In 1968, I married and resigned myself to working, helping put my husband through his senior year, and forgetting the silly notion of a baccalaureate. My husband graduated in 1969, turned to me, and said, "Now it's your turn.” I was terrified and refused the idea. He persisted, dragged me to a 
school advisor, and got me reenrolled. I finished my senior year in 1970 with a 4.0. My baccalaureate was in Spanish Literature.

Through my husband's prodding, I applied to the Master's Program at UCLA's School of Social Welfare. To my surprise I was accepted! My parents' response was, "Haven't you already graduated?" The years 1971 to 1973 (like all of my college years) were politically active years for me. The struggle for minority enrollment and curriculum content required great commitment and energy. I received my master's in Social Welfare in 1973.

From 1973 to 1986 I worked for Los Angeles County in various departments, Mental Health, Health Services, and Social Services; my positions ranged from psychiatric social worker to administrator. My clinical work by choice has always been with Latinos in the barrios.

In 1977, I was blessed with the birth of a wonderful daughter. In addition to my academic and professional responsibilities, the responsibility of passing on to my daughter the beauty of her Latino culture, which is her birthright, is one I also take seriously.

In 1986 I joined the faculty of the UCLA School of Social Welfare as a Fieldwork Liaison. This was a very challenging experience, in that this school was struggling with issues of cross-cultural conflict in terms of both the student body and the faculty. I left in 1987 to begin my doctoral studies in Social Welfare in this same school.

While I would like to believe that my doctoral studies were undertaken in a supportive and nurturing environment, I found that my ethnicity and socioeconomic background continued to be pointed out as some sorrowful legacy to be overcome. This is why I am so determined to continue and succeed. My own personal aspirations aside, the statistical evidence is that the Latino population in the Southwest is the single fastest-growing ethnic group in the country. Without an infrastructure of professionals and leaders, this population, my people, will not participate in government, economic progress, social welfare benefits, educational opportunities (how many cosmetologists do we need?), and technological achievement, and will, rather than being represented, be overseen by a nonrepresentative minority.

I would like to be part of that leadership. I believe that I can bring my life experience, educational achievement, and maybe some inspiration to students who lack role models like my Helen Miller Bailey. Historically, the timing is critical for the development of Latino leaders and professionals - not only to bring our people into the American mainstream but also to revitalize this country in the face of military, economic, and technological challenges from the rest of the world. 